\title{
CLINICAL AND MORPHOLOGICAL EVALUATION OF SNAKE VENOM DERIVED FIBRIN GLUE ON THE TENDON HEALING IN DOGS
}

FERRARO G. C. (1), MORAES J. R. E. (1), PEREIRA G. T. (2), MORAES F. R. (1), BUENO DE CAMARGO M. H. (1)

(1) Department of Veterinary Pathology (DPVE), School of Agrarian and Veterinary Sciences (FCAV), São Paulo State University, UNESP, Jaboticabal, São Paulo State, Brazil; (2) Department of Exact Sciences, School of Agrarian and Veterinary Sciences (FCAV), São Paulo State University, UNESP, Jaboticabal, São Paulo State, Brazil.

ABSTRACT: The aim of this study was to evaluate the effect of snake venom derived fibrin glue on the healing of the deep digital flexor tendon, during three periods. The tendon of the $2^{\text {nd }}$ digit of 30 thoracic limbs of dogs was partially sectioned for glue application. Biopsies were performed 7, 15, and 30 days post surgery for the clinical and morphological study of tendons. Analysis of the results showed that $73.3 \%$ of the tendons showed stump retraction and $16.6 \%$ moderate to excessive adherence, which affected sliding. There was a significant difference in the number of inflammatory cells among the three studied periods, being the highest on day 15 . The morphological analysis revealed a typical tendon healing process with a lower level of inflammation in the acute phase, facilitating the cicatricial maturation phase. Snake venom derived fibrin glue promotes the healing in dog flexor tendon.

KEY WORDS: dog, fibrin glue, snake venom, healing, tendon.

\section{CORRESPONDENCE TO:}

JULIETA RODINI ENGRÁCIA DE MORAES, Laboratório de Patologia Experimental e Comparada, Departamento de Patologia Veterinária, FCAV/UNESP, Via de Acesso Professor Paulo Donato Castellani, Km 5, 14884-900, Jaboticabal, SP, Brasil, Phone: 55163209 2662, Email: jrmoraes@fcav.unesp.br 


\section{INTRODUCTION}

The tendinous injuries are usually of traumatic origin and their effective treatment requests basic knowledge of the principles involved in tendon healing and their application in the specific biomechanical environment of the injured tendon. The ideal tendinous repair must, besides morphologically reconstitute the injured tissue, preserve the sliding function of the tendon, helping to maintain its movement capacity (30).

Peritendinous adhesions in flexor tendon surgery are still a great challenge, both in clinical and experimental practice (5). Attempts to prevent adhesions and improve the tendinous healing have been made with variable success. They include morphological and biomechanical trials with different suture materials and repair techniques (18), different postoperative managements (22), grafts (25), and different substances as corticosteroids (12), dextran 70 (8), collagen inhibitor (28), ibuprofen (37), sodium hyaluronate (39), aprotinin (14), 5-fluorouracil (19), TGB- $\beta$ (40), and fibrin glue (11).

Fibrin glue is currently used in the surgical treatment of traumatic and experimental tendon ruptures $(21,26,32,35)$. The main reason justifying its use is the smooth surface on the lesion site, preventing the formation of adherences during the healing process (3) and also increasing repair strength (38).

The objective of this study was to evaluate the clinical evolution of tendon sliding and the cellular kinetics of the inflammatory process of the Deep Digital Flexor Tendon (DDFT) healing of dog thoracic limbs during three periods, using snake venom derived fibrin glue associated with bubaline fibrinogen as a substitute to conventional tenorrhaphy.

\section{MATERIALS AND METHODS}

Thirty thoracic limbs from 15 healthy, adult mongrels $(10-15 \mathrm{~kg})$ were used. Dogs underwent a preliminary adjustment period ( 15 days minimum), when they received a balanced diet and water ad libitum; they were individually housed throughout the experiment.

The thoracic limbs were randomly divided into 3 experimental groups of 10. Each group corresponded to the day of evaluation after the glue application: $7^{\text {th }}, 15^{\text {th }}$, and $30^{\text {th }}$ days post surgery. 
After withholding food for six hours and water for three hours, animals received levomepromazine hydrochloride (1 $\mathrm{mg} / \mathrm{kg}$, intravenously) as pre-anesthetic, and tiletamine and zolazepam (10 mg/kg, subcutaneously) as dissociative anesthesia. Later, they received buprenorphine hydrochloride $(0.01 \mathrm{mg} / \mathrm{kg}$, subcutaneously) and penicillin $\mathrm{G}$ benzathine (40,000 UI/kg, subcutaneously).

The dorsal lateral region of the paw was shaved and prepared with povidine iodine solution. The skin and the subcutaneous tissue of the lateral region of the $2^{\text {nd }}$ digit were incised, followed by divulsion of the adjacent tissues. After that, the incision of the synovial sheath, location of the DDFT, partial transverse tenotomy (approximately $2 / 3$ of the diameter) between the $2^{\text {nd }}$ and $3^{\text {rd }}$ annular ligament, drying of the tendon stumps, application of two drops of fibrin glue, coaptation of tendon stumps for two minutes, and skin suture were performed.

After cleaning the surgical wound, a protective bandage was applied, using orthopedic cotton. The limb was immobilized using a PVC splint placed at $90^{\circ}$ on the carpal joint, providing protection during movement. We also used an "Elizabethan" type collar to restrict the dog's head movement. Animals underwent daily physical therapy, with biopsy.

On the day of biopsy the animals were subjected again to the anesthetic and surgical procedures as described before. Tendon segments containing approximately $10 \mathrm{~mm}$ were removed. Macroscopic alterations of tissue repair were evaluated at the moment of tendon collection, considering stump coaptation, adhesion formation, and sliding.

Tendon segments of approximately $5 \mathrm{~mm}$ from the $2^{\text {nd }}$ digit were prepared by the usual techniques for inclusion in paraffin or historesin. From each segment, 5- $\mu \mathrm{m}-$ thick longitudinal sections were made. At least five sections were mounted on a histological slide and stained with Hematoxylin-Eosin (HE) and Massom's Trichrome (MT). Each segment was morphologically analyzed for healing pattern.

Inflammatory cell count was made under binocular light microscope using $6.3 \mathrm{x}$ integrated eyepiece (Carl Zeiss ${ }^{\odot}$, Kpl $6.3 \mathrm{~mm}$, Austrian) and 40x lens, totaling 252x magnification. The area delimited by this eyepiece was measured as $0.0324 \mathrm{~mm}^{2}$ by micrometry. Ten microscopic fields were counted, randomly focused on the healing region in five sections of each slide, representing each limb on each day of observation. 
Evaluation of the three treatments on the number of inflammatory cells was performed by an entirely randomized design, with 10 repetitions. In an analysis of variance, the means were compared by the $F$ test at $1 \%$ probability. Mean differences were tested with the Tukey test at $5 \%$ probability level (27). Values were expressed as mean \pm standard error.

Fibrin glue is composed of the thrombin-like fraction from Crotalus durissus terrificus venom, cryoprecipitate from bubaline blood, and calcium chloride, obtained as per Thomazini-Santos (36). It was applied using a "Y" shaped syringe mixing the fractions $(300 \mu \mathrm{l}$ cryoprecipitate [syringe 1]; $250 \mu \mathrm{l}$ calcium chloride and $50 \mu \mathrm{l}$ thrombin-like fraction [syringe 2]) at surgery.

\section{RESULTS}

Twenty-two of the 30 tendons evaluated $(73.3 \%)$ showed slight to moderate stump retraction (approximately $2 \mathrm{~mm}$ ); the 30-day group showed the best coaptation (Figure 1). Adhesion to the synovial sheath and adjacent tissues was slight in 9 $(30 \%)$ and moderate to excessive in $5(16.6 \%)$, compromising sliding (Figure 2).

Seven days after surgery, the morphological findings showed tendon slit retraction on the scar area, epitendon varying from normal to thick, and a rare inflammatory infiltrate consisting of polymorphonuclear cells in the epitendon and sectioned region. Fibrocartilaginous cells were seen in the endotendon, especially in the proximal stump, and an amorphous substance with high amounts of fibrin, fibroblasts, and erythrocytes were seen in the scar region (Figure 3A, 3B, and $3 \mathrm{C}$ ).

On the $15^{\text {th }}$ day, epitendon thickness varied from normal to increased with pronounced inflammatory infiltrate. Mononuclear and fibrocartilaginous cells were seen in the proximal stump with signs of collagenous fiber reorganization with young modeled dense connective tissue, richly cellular proliferative loose connective tissue neovessels and fibroblasts (Figure 3D, 3E, and 3F).

On the $30^{\text {th }}$ day, a tendon slit retraction was seen in the scar area, filled with loose connective tissue with numerous freely oriented collagenous fibrils, creating a configuration of areolar tissue and scar in organization. Epitendon thickening and moderate cellularity, and spiral and crooked neovessels were also seen (Figure 3G, $3 \mathrm{H}$, and $3 \mathrm{I})$.

Analysis of variance showed significant difference $(p<0.01)$ for inflammatory cell count $\left(\right.$ cells $/ \mathrm{mm}^{2}$ ) between the three treatment times studied. The highest mean 
count of inflammatory cells (cells $/ \mathrm{mm}^{2}$ ) was on the $15^{\text {th }}$ day post surgery $(898 \pm 71)$, followed by the $30^{\text {th }}$ day $(41 \pm 6)$, and the $7^{\text {th }}$ day $(4 \pm 1)$. Comparison of means of the three treatment times by the Tukey test reveals significant difference was seen only on the $15^{\text {th }}$ day $(p<0.05)$ (Figure 4$)$.

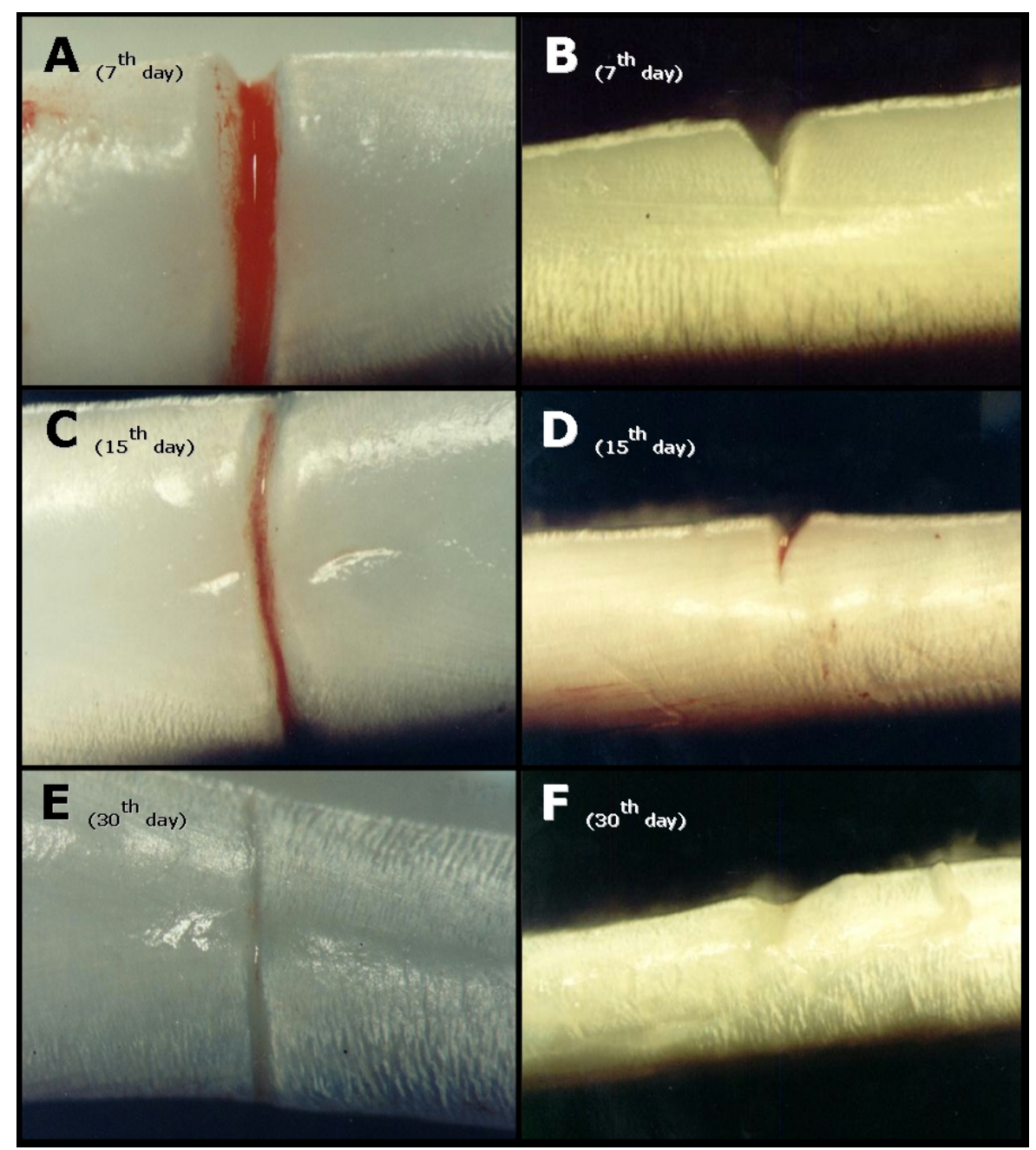

Figure 1: Photomacrographs of the deep digital flexor tendon segments of dog thoracic limbs using snake venom derived fibrin glue on the $7^{\text {th }}(A$ and $B), 15^{\text {th }}$ (C and $D)$, and $30^{\text {th }}(E$ and $F)$ days post surgery. Note: retraction of tendon stumps. Palm (A, $\mathrm{C}$, and $\mathrm{E})$ and lateral $(\mathrm{B}, \mathrm{D}$, and F) view. Stereomicroscope, magnification $\mathrm{x} 25$. 


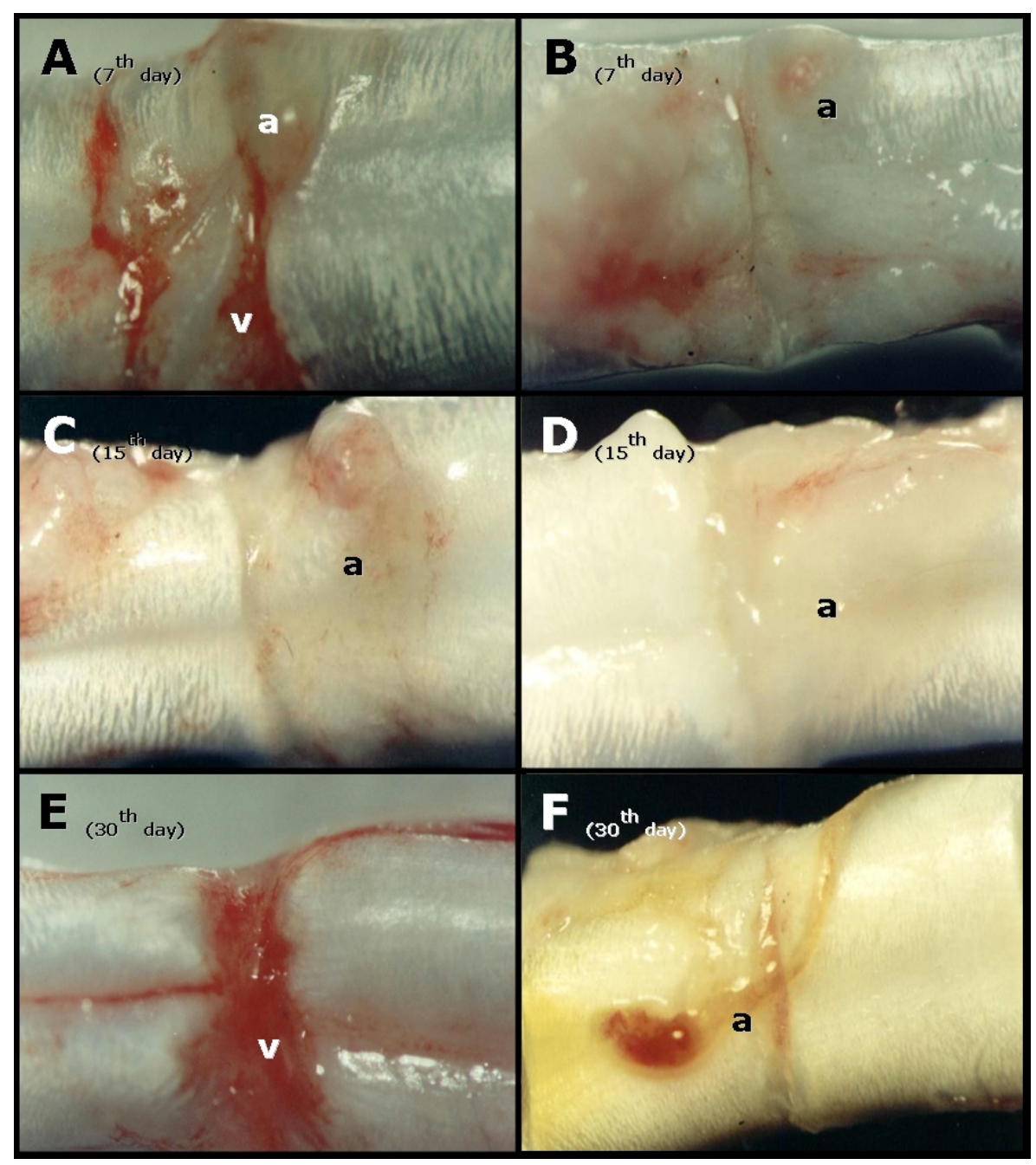

Figure 2: Photomacrographs of the deep digital flexor tendon segments of dog thoracic limbs using snake venom derived fibrin glue on the $7^{\text {th }}(A$ and $B), 15^{\text {th }}$ ( $C$ and $D)$, and $30^{\text {th }}$ ( $E$ and $F$ ) days post surgery. Note: adhesion (a) and intense vascularization (v). Palm view. Stereomicroscope, magnification $\mathrm{x} 25$. 


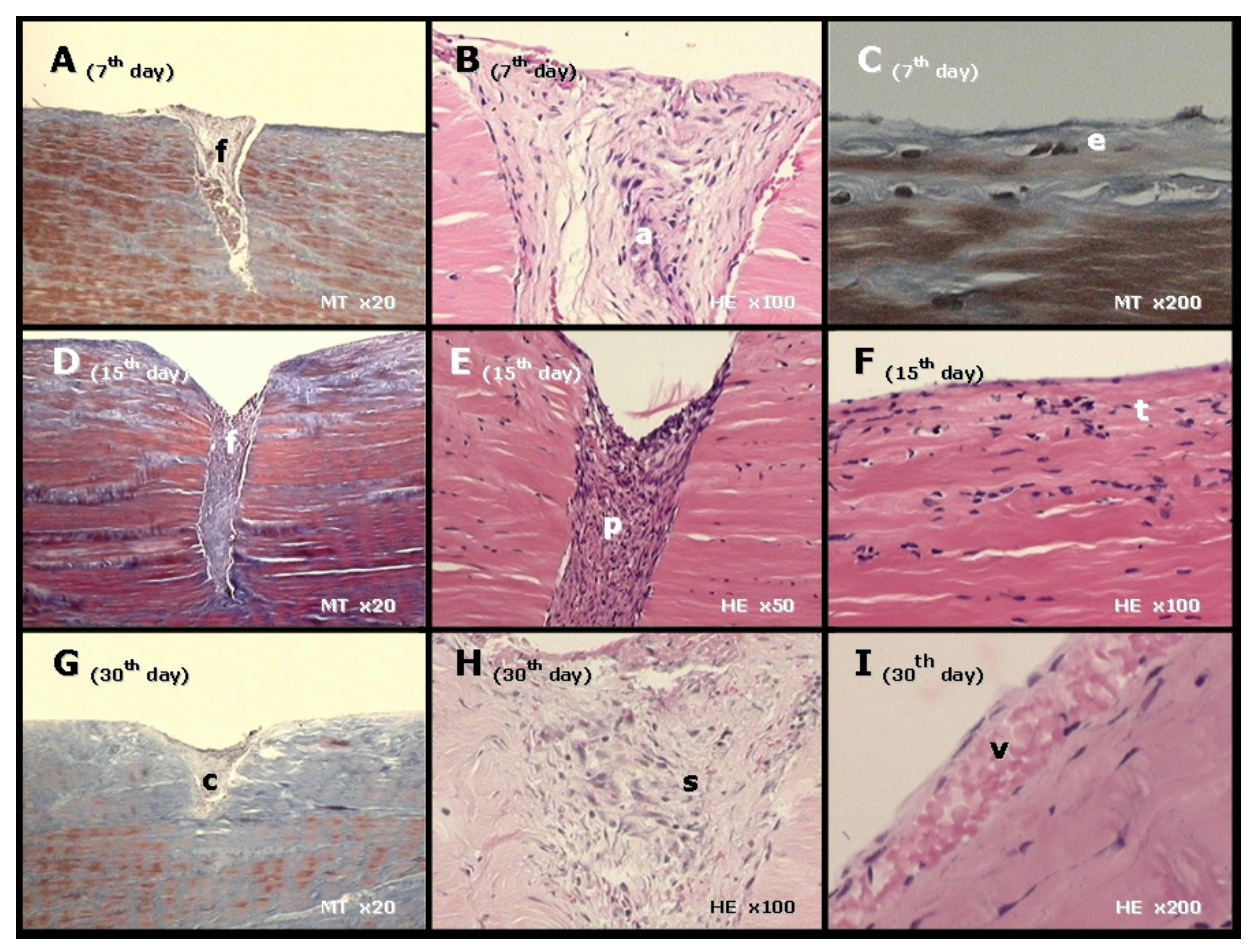

Figure 3: Photomicrographs of the deep digital flexor tendon segments of dog thoracic limbs using snake venom derived fibrin glue on the $7^{\text {th }}, 15^{\text {th }}$, and $30^{\text {th }}$ days post surgery. Embedded in paraffin (A-H) and historesin (I). HE (haematoxylin-eosin) and MT (Massom' trichrome) staining. Objective: $x 4(A, D$, and $G), x 10(E), x 20(B, F$, and $\mathrm{H})$, and $\mathrm{x} 40$ (C and $\mathrm{I})$.

Note:

7th day - retraction of tendon slit (f), no thickened epitendon (e), amorphous scar tissue (a);

15th day - retraction of tendon slit (f), richly cellular proliferative loose connective tissue $(p)$, epitendon varying from normal to thick $(t)$;

30th day - tendon slit with loose connective tissue (c), scar in organization (s), epitendon with pronounced neovascularization (v). 


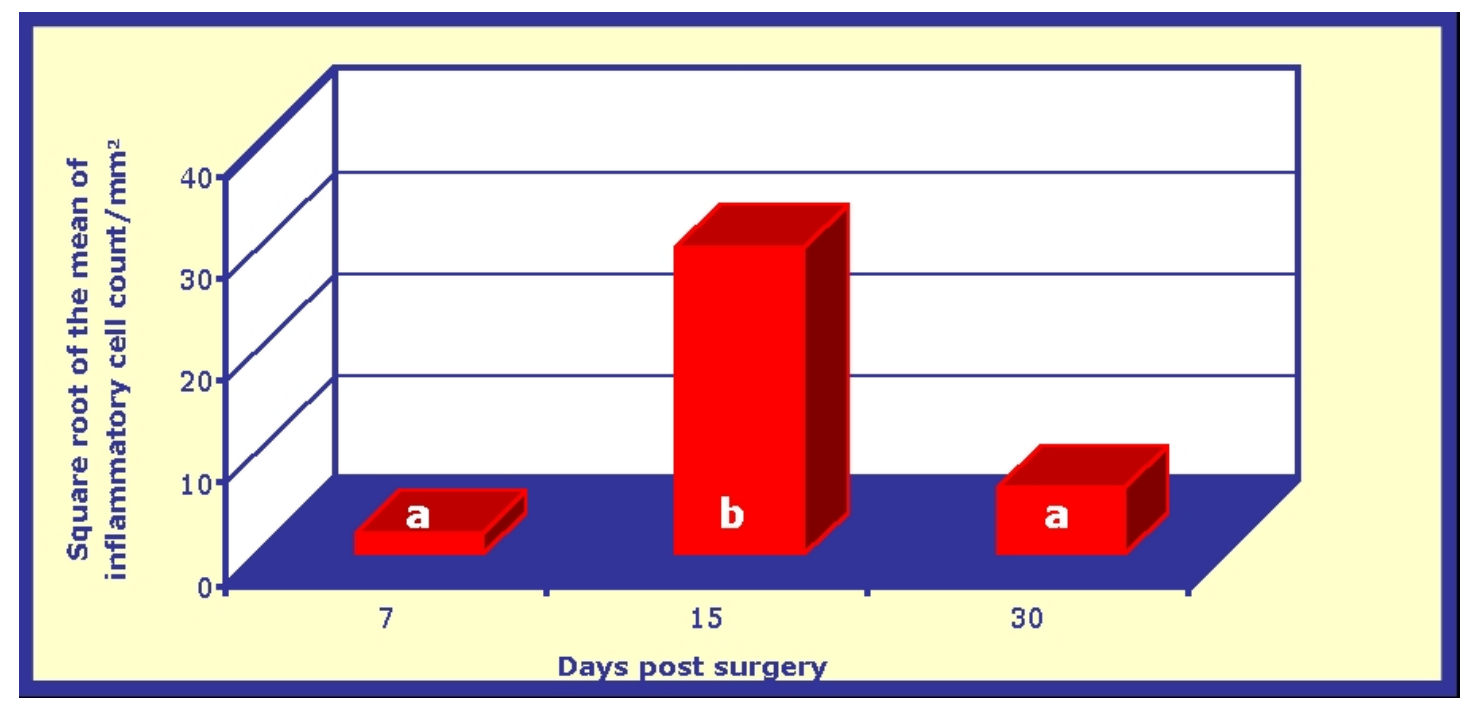

Figure 4: Mean variation and inflammatory cell count $/ \mathrm{mm}^{2}$ in the surgical scar region of the deep digital flexor tendon segments in dog thoracic limbs using snake venom derived fibrin glue on the $7^{\text {th }}, 15^{\text {th }}$, and $30^{\text {th }}$ days post surgery. Means with equal small letters above the bars are not different by the Tukey test $(p>0.05)$.

\section{DISCUSSION}

Flexor tendon repair is limited by the formation of adhesions, which restrict mobility and reduce limb function in a significant proportion of cases (6). However, these adhesions only develop if a combination of tenorrhaphy, immobilization, and a concurrent digital sheath injury is inadequate (17).

Results showed that $16.6 \%$ of tendons had moderate to excessive adhesion. This may be attributable to excessive tendon manipulation during surgery and/or to the fibrin glue, which due to its low viscosity infiltrated the tissues adjacent to the section site because of the technique used.

The most important factor to recover sliding function is not to prevent adjacent tissue adhesion but to reduce the scar slit that is the quantity of fibrous tissue. This reduction requires minimum traumatism, absence of hematoma and abscess, and rest to allow optimum healing. An adhesion rupture makes the inflammatory process and the scar formation acute again. The regenerated tendon with preservation of sliding function indicates a remodeling of the scar tissue, maintaining enough morphological architecture for not harming its sliding function. It is therefore important not to rupture the adhesions, but to remodel the scar (10).

In this study, the results showed that immobilization associated with adequate daily passive movement of the operated on digit also helped to prevent the formation of 
excessive adhesion to the neighboring tissues, favoring less formation of fibrous connective tissue and allowing better sliding in most operated on tendons, as reported in several other experimental species $(4,18)$.

Adhesion in injured tendons is common since the repair tissue includes several cell types that organize into a single unit (24). The formation of space favors the migration of fibrous connective tissue, compromising tendon sliding (9).

In this study, the partial section of the tendon caused secondary retraction between tendon stumps in $73.3 \%$ of the analyzed tendons. This can be attributed to the high tension required in tendon extremities, since the glue did not provide enough resistance in the ruptured area to support traction, and also to the surgical technique and the post surgery rehabilitation program. However, previous studies report that the secondary separation of stumps, less than or equal to $2 \mathrm{~mm}$, did not compromise flexor tendon healing in dogs subjected to tenorrhaphy and postoperative physical therapy (29).

The classic study proposed a useful division of the tendinous healing process into three phases: exudation and fibrinous union; fibroplasia; and maturation and organization $(16,39,40)$. When a tendon is injured a wound module is formed, consisting of inflammatory cells, fibroblasts, and capillaries (13). The collagen produced by fibroblasts is initially composed of fibrils that are small in diameter and randomly oriented (2). As the fibrous tissue matures, fibrils that are larger in diameter predominate and, together with other constituents of the scar, reorient along the lines of stress, eventually resembling normal tendon tissue (23). These morphological changes coincide with an increase in the mechanical strength of the tendon at the repair site (31).

The morphological results revealed reactive epitendon with low cellular density on the $7^{\text {th }}$ day after surgery. The presence of mononuclear cells, characteristic of chronic inflammatory process, and the formation of scar tissue between the tendon stumps were seen on day 15 . On the $30^{\text {th }}$ day, there was a pronounced neovascularization and crooked and spiraled blood vessels in the epitendon. The collagen in the scar was arranged in parallel bundles substituting the repair connective tissue and collagenous fibrils with free arrangement, creating a loose areolar tissue formation. Except for the low cellular density in the inflammatory infiltrate on the $7^{\text {th }}$ day after surgery, these results were also seen by other authors in dog tendons $(18,20)$. 
Several studies have suggested benefits in the use of fibrin adhesives in traumatic $(7,21,26,38)$ and experimental $(11,32,33,34,35)$ ruptures of tendons in different species. They have reported that these adhesives act as a surface that favors fibroblast migration with mitogenic influence that increases collagen secretion and its early stratification $(7,24)$ in addition to increased repair strength, decreased surgical time and post surgery mobilization in some cases $(33,34,38)$. However, not all of them reported its beneficial effects on tendon healing $(1,5,15)$; but they admitted possible flaws in the pre-established design or technique used $(7,15)$.

The clinical and morphological results of this study show satisfactory use of snake venom derived fibrin glue in flexor tendon healing of dogs. We also highlighted that the change of technique for applying the glue using a sterile insulation to keep the surgical site separate from the neighboring tissues during glue components reaction can effectively reduce the level of adhesion as described by other authors in rabbit tendons $(5,11)$.

Finally, the use of snake venom derived fibrin glue prevented excessive formation of adhesion, inhibiting inflammatory cell migration on the $7^{\text {th }}$ day post surgery and facilitating the maturation stages of the tendon healing process. Therefore, the glue can be used as promoter of the healing of flexor tendons in dogs.

\section{ACKNOWLEDGEMENTS}

The State of São Paulo Research Foundation (FAPESP) for financing this study; Center for the Study of Venoms and Venomous Animals (CEVAP), São Paulo State University (UNESP) at Botucatu, São Paulo, Brazil; Laboratory of Micology of the Department of Clinical Analysis of the School of Pharmaceutical Sciences (FCF), São Paulo State University (UNESP) at Araraquara, São Paulo, Brazil; Laboratory of Division into Fractions of the Blood Bank of the Ribeirão Preto School of Medicine (FMRP), São Paulo University (USP) at Ribeirão Preto, São Paulo, Brazil; FortDodge $^{\odot}$ at Campinas, São Paulo, Brazil; Fri-Ribe ${ }^{\odot}$ at Pitangueiras, São Paulo, Brazil. 


\section{REFERENCES}

1 BOSCH P., HERTZ H., LINTNER F., NOWOTNY R., ENGEL A. Experimentelle Sehnenklebung. In: COTTA H., BRAUN A. Fibrinkleber in orthopadie und traumatologie. Stuttgart: Thieme-Verlag, 1982: 187.

2 DAVISON PF. Tendon. In: JAYSON MIV., WEISS JB. Collagen in health and disease. Edinburgh: Edinburgh Churchill Livingston, 1982: 498-505.

3 EIKEN O., LUNDBORG G., RANK F. The role of the digital synovial sheath in tendon grafting. Scand. J. Plast. Reconstr. Surg., 1976, 9, 182-9.

4 FEEHAN LM., BEAUCHENE JG. Early tensile properties of healing chicken flexor tendons: early controlled passive motion versus postoperative immobilization. J. Hand Surg. Am., 1990, 15, 63-8.

5 FRYKMAN E., JACOBSSON S., WIDENFALK B. Fibrin sealant in prevention of flexor tendon adhesions: an experimental study in the rabbit. J. Hand Surg. Am., 1993, 18, 68-75.

6 GELBERMAN RH., MANSKE PR. Factors influencing flexor tendon adhesions. Hand Clin., 1985, 1, 35-42.

7 GLUCKERT K., PESCH HJ., WESELOH G. Fibrinklebung bei sehnenlasionenexperimentelle erfahrungen und klinische aspekte. In: SCHEELE J. Fibrinklebung. Berlin: Springer-Verlag, 1984: 221.

8 GREEN S., SZABO R., LANGA V., KLEIN M. The inhibition of flexor tendon adhesions. Bull. Hosp. Jt. Dis. Orthop. Inst., 1986, 46, 16-21.

9 GREENWALD DP., HONG HZ., MAY Jr. JW. Mechanical analysis of tendon suture techniques. J. Hand Surg. Am., 1994, 19, 641-7.

10 JOHNSTON DE. Tendons, skeletal muscles, and ligaments in health and disease. In: NEWTON CD., NUNAMAKER DM. Textbook of small animal orthopaedics. Philadelphia: Lippincott, 1985: 65-76.

11 JONES ME., BURNETT S., SOUTHGATE A., SIBBONS P., GROBBELAAR AO., GREEN CJ. The role of human-derived fibrin sealant in the reduction of postoperative flexor tendon adhesion formation in rabbits. J. Hand Surg. Br., 2002, 27, 278-82.

12 KAPETANOS $\mathrm{G}$. The effect of the local corticosteroids on the healing and biomechanical properties of the partially injured tendon. Clin. Orthop., 1982, $163,170-9$. 
13 KETCHUM LD. Tendon healing. In: HUNT TK., DUNPHY JE. Fundamentals of wound management. New York: Appleton-Century-Crofts, 1979: 500-23.

14 KOMURCU M., AKKUS O., BASBOZKURT M., GUR E., AKKAS N. Reduction of restrictive adhesions by local aprotinin application and primary sheath repair in surgically traumatized flexor tendons of the rabbit. J. Hand Surg. Am., 1997, 22, 826-32.

15 LUSARDI DA., CAIN Jr. JE. The effect of fibrin sealant on the strenght of tendon repair of full thickness tendon lacerations in the rabbit Achilles tendon. J. Foot Ankle Surg., 1994, 33, 443-7.

16 MASON M., ALLEN HS. The rate of healing of tendons. Ann. Surg., 1941, 113, 424-59.

17 MATTHEWS P., RICHARDS H. Factors in the adherence of flexor tendons after repair: an experimental study in the rabbit. J. Bone Joint Surg. Br., 1976, 58, 230-6.

18 MORAES JRE. Estudo comparado dos aspectos morfofuncionais de tendões na constituição normal e na evolução do processo cicatricial. Jaboticabal: Universidade Estadual Paulista, Faculdade de Ciências Agrárias e Veterinárias, 2001. 172p. [Tese - Livre Docência]

19 MORAN SL., RYAN CK., ORLANDO GS., PRATT CE., MICHALKO KB. Effects of 5-fluorouracil on flexor tendon repair. J. Hand Surg. Am., 2000, 25, 242-51.

20 NESSLER JP., AMADIO PC., BERGLUND LJ., AN KN. Healing of canine tendon in zones subjected to different mechanical forces. J. Hand Surg. Br., 1992, $17,561-8$.

21 PAAR O., BERNETT P. Therapy of Achilles tendon rupture in athletes. Advantages of fibrin gluing. Fortschr. Med., 1984, 102, 1106-8.

22 PALMES D., SPIEGEL HU., SCHNEIDER TO., LANGER M., STRATMANN U., BUDNY T., PROBST A. Achilles tendon healing: long-term biomechanical effects of postoperative mobilization and immobilization in a new mouse model. J. Orthop. Res., 2002, 20, 939-46.

23 PEACOCK E. Physiology of tendon repair. Am. J. Surg., 1965, 109, 283-6.

24 PEACOCK EE. Wound repair. 3. ed. Philadelphia: WB Saunders, 1984. 544p. 
25 RAISER AG., GRAÇA DL., PIPPI NL., ZINN LL., SILVEIRA DS., BORDIN AI., BAIOTTO GC., RIOS MV., SILVEIRA AFD. Homoimplante ortotópico de tendão calcâneo em cães. Conservação, assepsia e implantação. Cienc. Rural, 2001, 31, 89-94.

26 RUPP G. Die fibringeklebte Achillessehnenruptur. In: COTTA H., BRAUN A. Fibrinkleber in orthopadie und traumatologie. Stuttgart: Thieme-Verlag, 1982: 140.

27 SAS INSTITUTE INC. SAS/STAT User's guide - version 6. Cary, 1995.

28 SCHWARZ RL. Modeling tendon morphogenesis in vivo based on cell density signaling in cell culture. J. Math. Biol., 1996, 35, 97-113.

29 SILVA MJ., BOYER MI., GELBERMAN RH. Recent progress in flexor tendon healing. J. Orthop. Sci., 2002, 7, 508-14.

30 SPURLOCK GH. Management of traumatic tendon lacerations. Vet. Clin. North Am. Equine Pract., 1989, 5, 575-90.

31 STEINER M. Biomechanics of tendon healing. J. Biomech., 1982, 15, 951-8.

32 THERMANN H., BECK A., HOLCH M., BIEWENER A., BOSCH U., FRERICHS O. Functional treatment of acute Achilles tendon rupture. A histological, immunohistological and ultrasonographic analysis of the animal model. Unfallchirurg., 1999, 102, 447-57.

33 THERMANN H., FRERICHS O., BIEWENER A., KRETTEK C. Healing of the Achilles tendon: an experimental study. Foot Ankle Int., 2001, 22, 478-83.

34 THERMANN H., FRERICHS O., BIEWENER A., KRETTEK C., SCHANDELMEIER P. Functional treatment of acute rupture of the Achilles tendon. An experimental biomechanical study. Unfallchirurg., 1995, 98, 50713.

35 THERMANN H., FRERICHS O., HOLCH M., BIEWENER A. Healing of Achilles tendon, an experimental study: histological, immunohistological and ultrasonographic analysis. Foot Ankle Int., 2002, 23, 606-13.

36 THOMAZINI-SANTOS IA. Adesivo de fibrina derivado de veneno de serpente: efeito da adição do ácido epsilon-aminocapróico, do ácido tranexâmico e da aprotinina na coaptação das bordas cirúrgicas em incisões de pele de ratos. Botucatu: Universidade Estadual Paulista, Faculdade de Medicina, 2000. 132p. [Tese - Doutorado] 
37 TSAI WC., TANG FT., HSU CC., HSU YH., PANG JH., SHIUE CC. Ibuprofen inhibition of tendon cell proliferation and up regulation of the cyclin kinase inhibitor p21CIP1. J. Orthop. Res., 2004, 22, 586-91.

38 VOLLMAR D. Kombination fibrinklebung mit chirurgischer naht bei Achillessehnenruptur. In: COTTA H., BRAUN A. Fibrinkleber in orthopadie und traumatologie. Stuttgart: Thieme-Verlag, 1982: 138.

39 WIIG M., ABRAHAMSSON SO., LUNDBORG G. Tendon repair: cellular activities in rabbit deep flexor tendons and surrounding synovial sheaths and the effects of hyaluronan - an experimental study in vivo and in vitro. J. Hand Surg. Am., 1997, 22, 818-25.

40 YALAMANCHI N., KLEIN MB., PHAM HM., LONGAKER MT., CHANG J. Flexor tendon wound healing in vitro: locate up-regulation of TGF- $\beta$ expression and functional activity. Plast. Reconstr. Surg., 2004, 113, 625-32. 